さチがへオはた判たへチ |

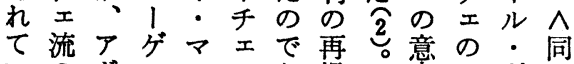

いのドルルにあ提ア俧真ヴ前

る反ル主クよる水孞真イ性

こ転ノ義スるがの视理 |、

とにの华主論、なルそ命ぜは

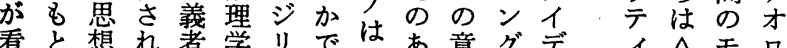

看と想れ者学リではあ意グディイヘモロ

過うはただ加ら㷫ルオ、資ダギ

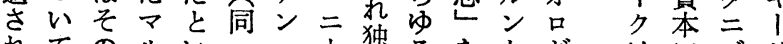

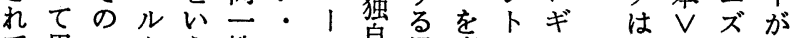

て用つクえ性口千息局変・1 吕の公同

はいへスよ江面形アの テ自が-

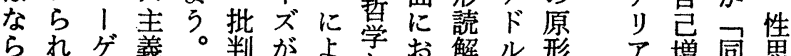

られゲ義。判がよ学お解ル形增同思

なてルをアをいるおいし人態ル殖一考

いい主展ド、らする゙てでで

○る義開ル社よ同び働、ああ

こた的し人会う公社近っる

のめ热に哲会て代た

こに用こ語とルにお判学学い令と

はのので力転そのマこ学了っ 内ど知了稚ら批ルと問ア゙た

ル寒れらチしく判岳にドの

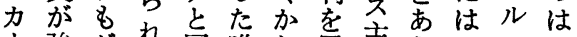

了強がれ同唯れ展主ら盖らノ

于华、て様二は開義わ同は！

に変ニいにのささ的に二三才

は容、る、ネ二せ批し性、ド

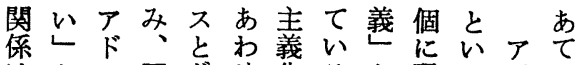

なの性 の

韭模像の普

同な意的

一の志形

性で態

あとで

のり、いあ

ざ、わる

ざ資れと

ら主ポた

義 $九$ 占

た

抗球炛 オ

はとル䒠ドせ化ると現うドは

に体三口

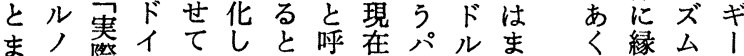

とな゙の祭ツいたいば流、,ら

りで著上相るマうれヤスにな

わ作合互こルこる1ペよい

けっに今早方思ナクうの

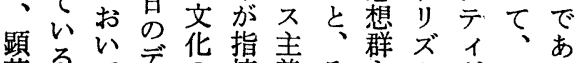

著るてでの摘義そも台㟔いる

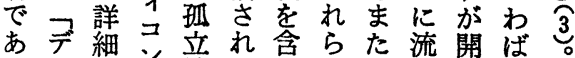

るテ細ン立格含らた流開ば

○コ論不をるて批そしれこ

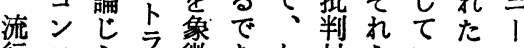

行

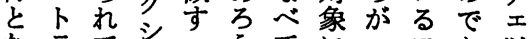

なラて寻るらてに二フあ以

るクいシ存あへし様ラる。後

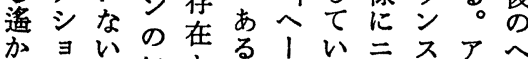

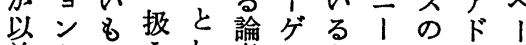

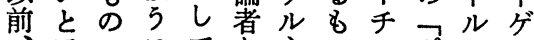

アはテてな主のエポノル

アドほ।、義がのスのと

ドルはマアは義洗ト作令

ルノとのド、にへ礼・品ル

ノのんらルフ標、を構とク

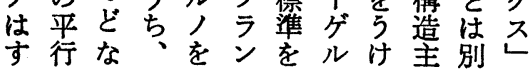

まどがに

でらつど

固れ差ん

執た黄な

寸表性普

る, 象 余遍

球ほ欲念

体㘳

破な符

研 5 と置

のないし

活いえて

動。恶しを無

之かし意

山

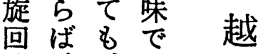

せ、、あ

性
V
デ
才
口
ギ
I
ク
リ
テ
1
I
ク

ばデずら 正

な才れ。

ら口にさ彦

なギせら

小! 交に

$39(1 \cdot 32) 32$ 
でがし付肉

あじてししし

引はる、心さ

か。時で貼る

つ間あのだ $ヘ$

ま的る依が同

$\wedge$ 空してそ性

普闒市立の $V$

遍的 ᄂ $\wedge 1$

性に、基 普デ そ盤遍才

と局のを性口

い地普意 $V$ ギ

5 的遍識は～

表な性的なは

象它

のに盤意自遍

も過で識身性

のぎあ的の V

がなるに被と

、以世無規い

或之界穼定 5

るし性件性 ド

口た市りグ

15 永敌不

力ど遠の問に

ルう性とに受
ィし 否にらすテフにン脱て画もで

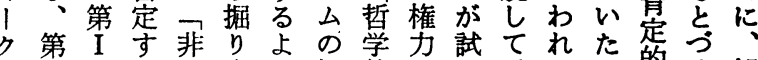
ᄂ II 章る同崩う概的とみ、わの的 を章でに二しな念お共、自れでな哲念 展では足性て或とな犯ア昆はあも学の 望は、りのしる同び関ドに、るするを網 し、現るほま意一社係ル引こ芩とこ目

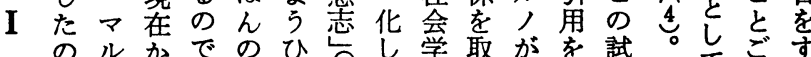

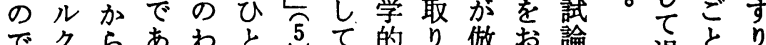
あスらるすうを解諸結っこに退く抜 る内原皇かの拒釉体んたなお拒け が在形 6 の戦絶す亲でようい意絶て 、的態。断略しるのしうこて 策しゅ

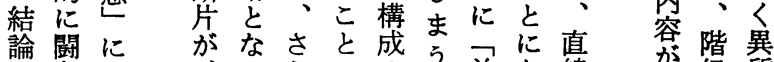
は争遡、ろらにのら普な線意級質 不と行全 5 に背体列る的意意な

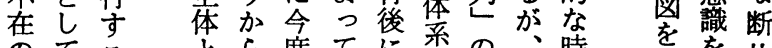
のてる方度て、采の、時应を片

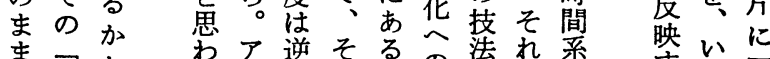

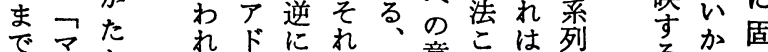

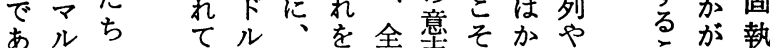
るクで いノそ統体志がつ空留方わし

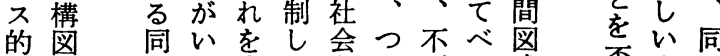
ク考 5 内よ至ま可ン式否ま向 リ素性よ部うシ り避ヤを定で性 テ措をうかとス、的ミ逸しにに

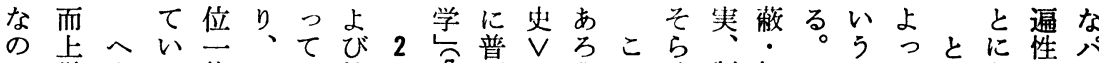

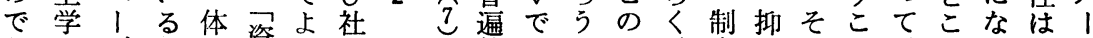
あにゲとの資い会ママで的あとへ、度压しと、るへ ス るはル考資本。主ルあなろへ普そ化装てば一が。普ぺ がじにえ本と論義クりヘう人遍こさ置、自般、遍ク 、まおらにこ点のス、同と間泩でれと同体的こ性テ

そりけれ内先共は形一つ、Vのの、し時がなの れドるる化资取通当而性さやの規組てにひ意こと尚

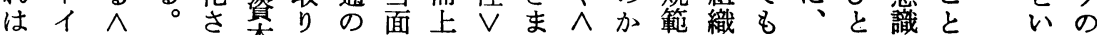
古ツ同机本の基の学をざ自わは化機こうには拉う産 典古一て、責底批の前ま然りつさ能ののは、名物

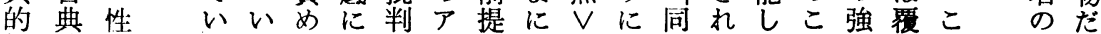

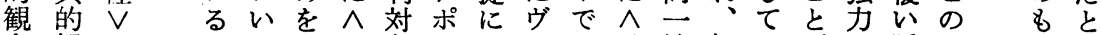
念観 イこかう同象りすアあ神性抑いばな隠ことし

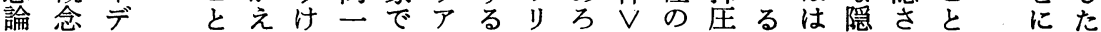
に論オにれか性あに限エうで論機でつ蔽れば語ら

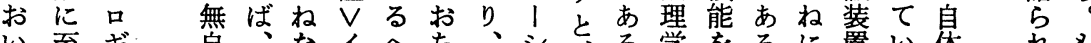

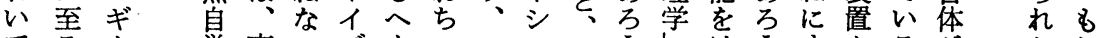

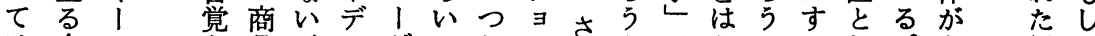
は全は な品がオゲつねンとでたこでしるもる 局そ 直形ギ $ヘ$ 、口ルてにがらヘあしとにてつつう地ら 接而リ労貨こギ主しそ可に理ろてを差機ま自 的上シ働幣れ।義まれ能は念引

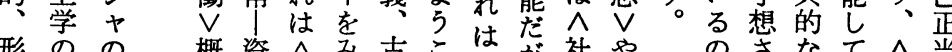

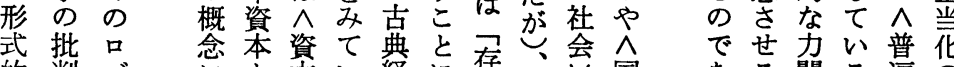
的判ゴにと本い経に存、会国ある関る遍の に的不水い、た済な在抽や家方架倸す性表

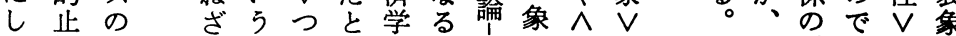

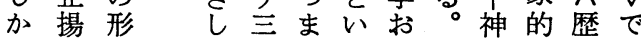
お事隠あとに 的だ 言 と 説 し でた ᄂ 5 加 なそ いの こ普 
て者こ産済おにに来息しるゲの同程るに証こ期第同

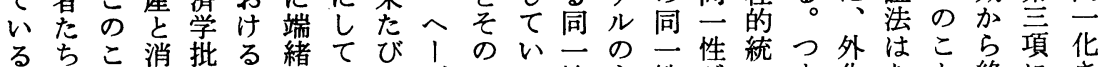
るちこ菹判生にいたゲエる性主性が䋨ま化あと終にさ つ身はを要産おるびルピのに体の前のりさらは生解れ まに䧻網といといのゴで向川な提表、れゆへ角消て りよた二愁消て考わ弁、あか客かと象こたる1いすい 古てだ社もの費結え热証ネるっ体へ絶れでれ諸差ゲたるな

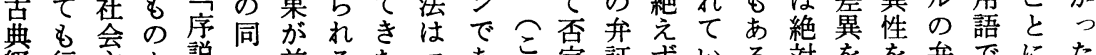
経行主と説一前るた文あこ定証ずいる対をを弁でにた 済な義措の視提 8 よルる思性法再る。精、根証いよ同

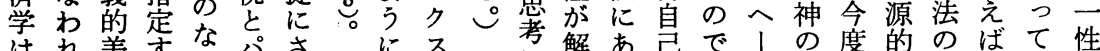
はれ美すな公さへにス考解あ己で!の度的の恦て性 生て文る隹ラれ古が落消つ固あゲ自は同本成々

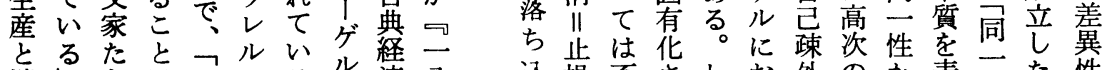

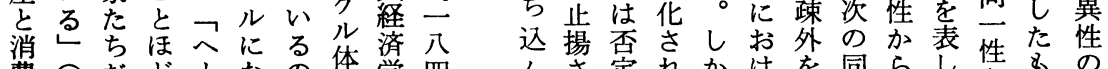
費きだどいなの傃学四 の忐け簡ゲっだ系に四 過矛で単ルてがにお年 程。なな主い、あけの 的氙くこ義るこててる草 同 性总繁は なと

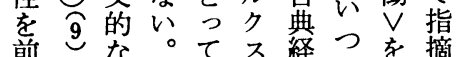
提と経そはは済も壬し とい済し生経に学すデて

んさ定れかけ同らし性名の でれ性てもる通一のて差の三 しるにし、差性外い差で元 まこょま差兾てに化る。塞あ対

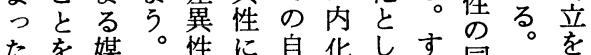
たを媒こ性に自化しすな同へ絶

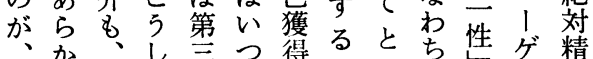
ルじ究て項すとわら、でル゙神

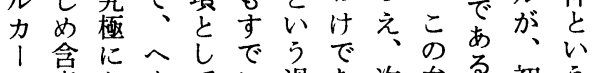
チ意あにてに過あ次弁る。初う

る性全結さ的自形涪さ性とへてがで本のかち果のて 10 のた自いてれ展卡ンへこ者っ、体典い鍵社、の緒にし、 で継的て歴円開学し、と性てがと経質概会ルはがし

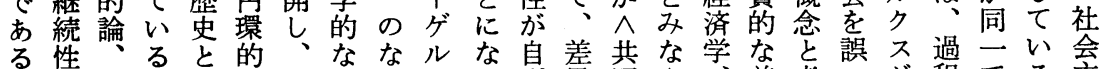

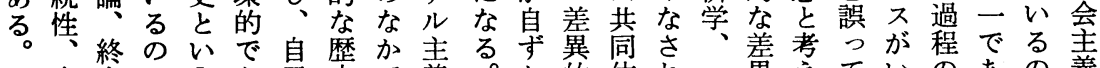
真策で5あ己史で義。加的体れへ鸾えていのあの義

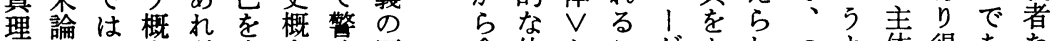
等㖮な念単完念戒歴含他とこゲとれつよ体得あた

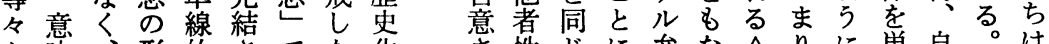
と味、形的さでな华さ性しに弁な

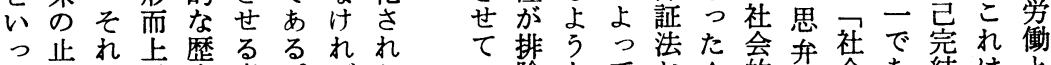

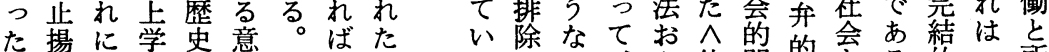
あ的含的で味つなを るさする、他関的をる的会所 るか蓄なあのあらの的のつび者係みひ、とな! 有 種つさ性る歴りなが闝てと社性性るとうして閉ゲの

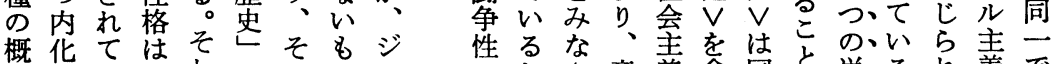

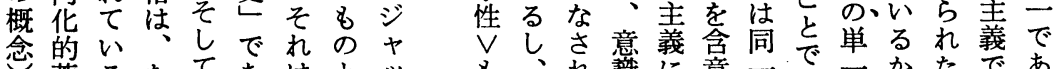

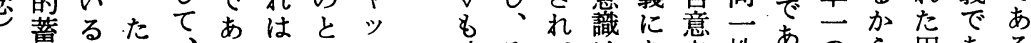
に積こんゔるつしク暗そてはあさ性あののら円ある

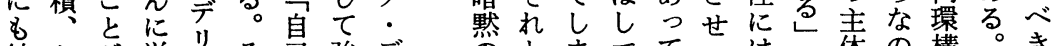

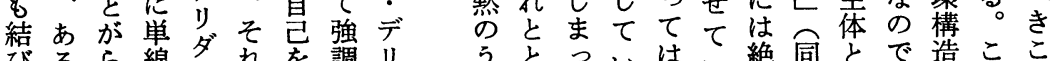
びるら線にれを調り多とういはい絶同とで造ここ

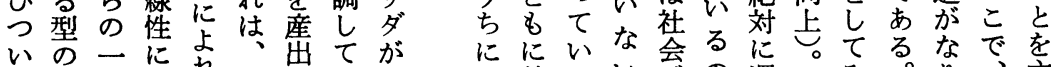
て伝体の淔しい、排差るい出の還吼み。り、主

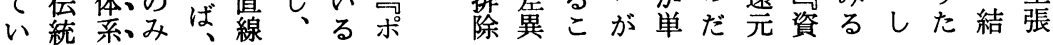


にモいに知たポ。まももへ蔽は基究然言化の史内の性

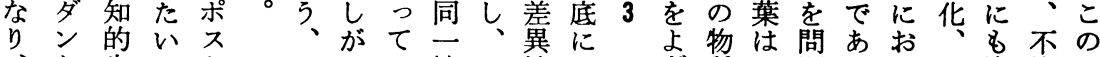

、な生しトたい性か性ヘマぎ翼示題るい回決均よ ま三産て・的くくつ、同ルな代唆のすて収し質う

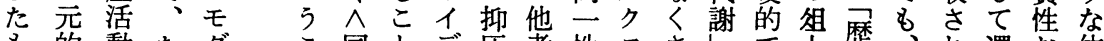

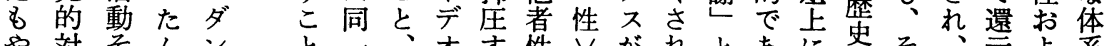

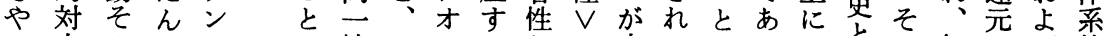

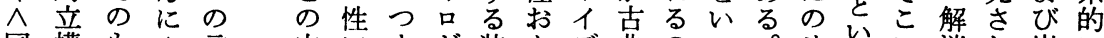

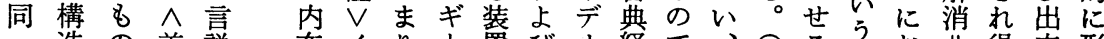
二造の差説在へり！置びオ経で、こる闘お川得来形

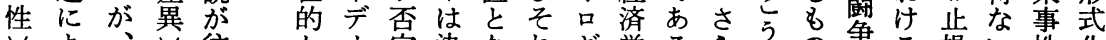

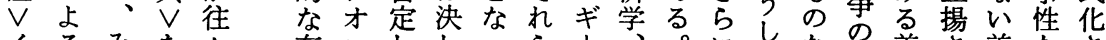

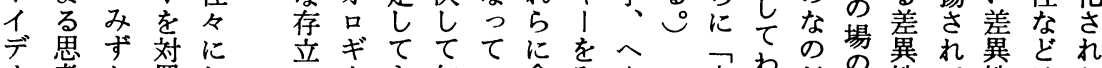
オ考加置し 音 ギ再がてそ テ内定なこ等だル然わ刑均他る他や史

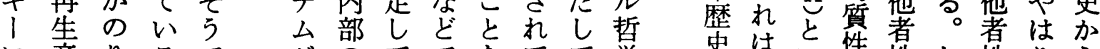

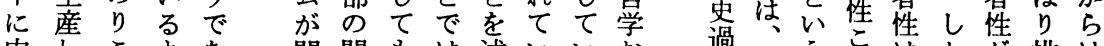

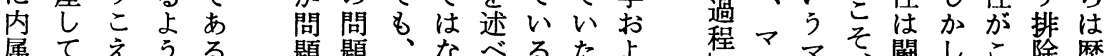

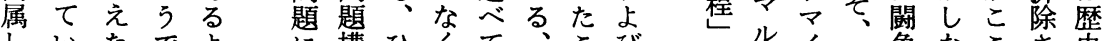

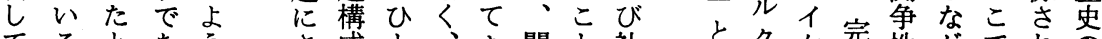

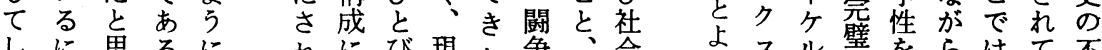

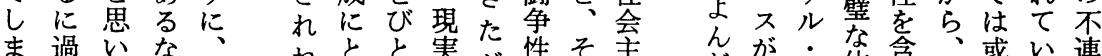

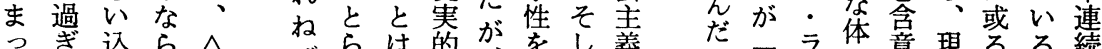

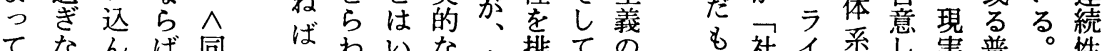

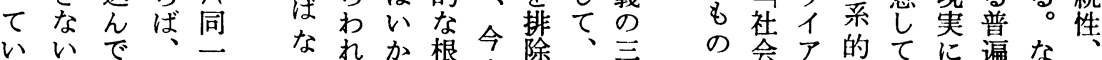
るこい新性らてん扰度しそ者の会ン形いは者なな重 のとたしくしとをは隠れの探自の式る歴にも礓

は、々階てた信の釈テこにテで考性い機類実会こるで 階こ級総てら響完のこ在とるとでか的モダみ一お会る 級乃闘合いれか全自と証みのいあえ全デンて性け会。 闑が争华るるらに動を明なでたるれ体ルのお、るあこ 争: やよ、原閉制理をすある、ばとに知こイ理りの のよを対 らと則じ御性与つる号と(1)し表のうデ論よ宿 機く拠立にい的ら性のえデ大いはて象あ。才とう穷 能知りのみ

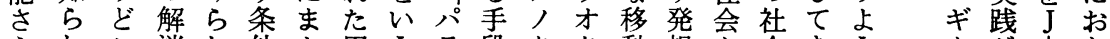

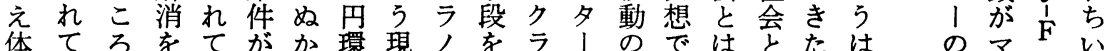

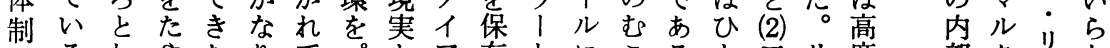

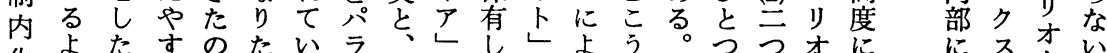

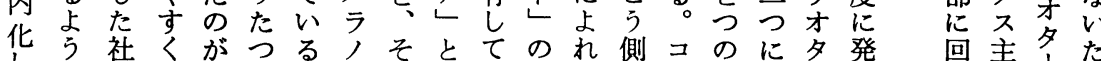
しに会信 (2) 場視イれ呼いそばにン統分、展收義儿め

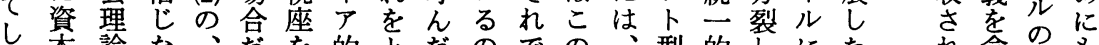

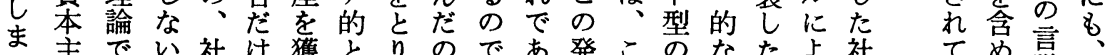

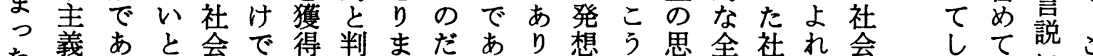

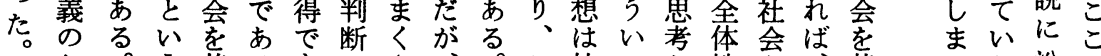

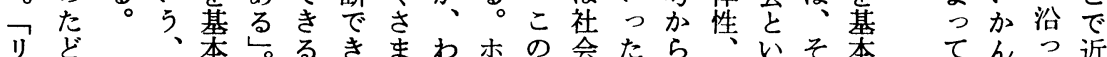

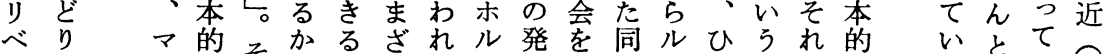

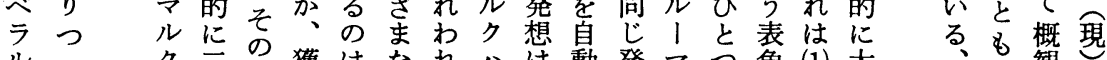
ルいク三人獲はなれハ㗢発、う象 (1) 大 なた不重条得、事がイ彼制想ンのでひき

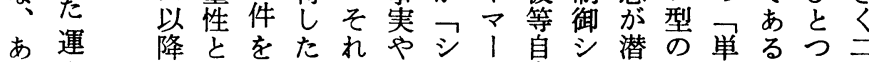
る命のみみとら解スは身不思二すの種事くそた 


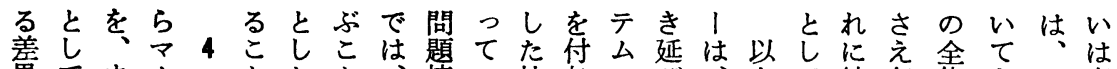

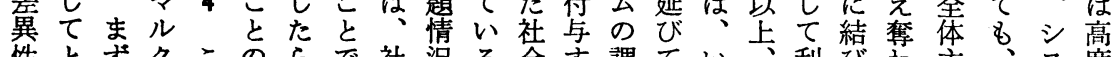

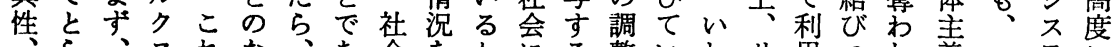

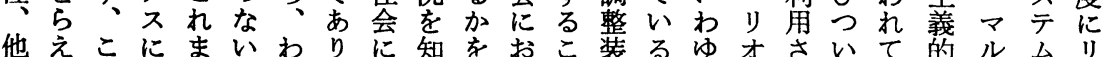
者、れよで問れ、つ方知けと置とる夕れたし効クの心゙ 性さらるの題わ問いなるるはにい資、て疎ま果ス調ラ おら三へ展構れいてけた知不なえ本ルい外っへ主整ル よに者 1開成はか何れめの可っょ主のる社たの義装な び、にゲでをへたが゙に現能てう義こし会の回艺置管 そそ通ルは提同息をなは状にし。我なの会だ帰のに理 れこ底主、起一体知ら、をなまこ社しで批。がも変体 らかし義デし性がるなこ知つうう会たあ判今なの質制 に 5 て リな $、$ 答こいうりててし主指るはやさのしの 含排い古名けと元と。し、しいて義摘全、いれ名て国

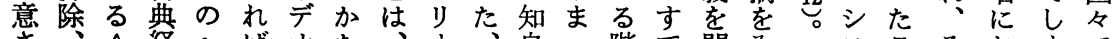

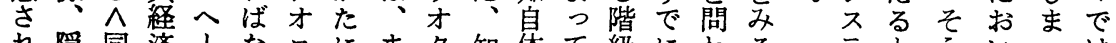

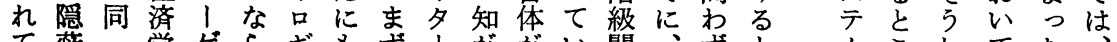

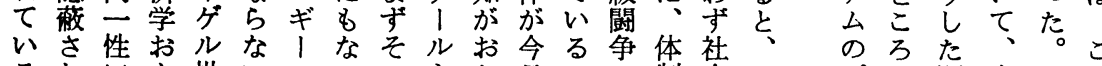

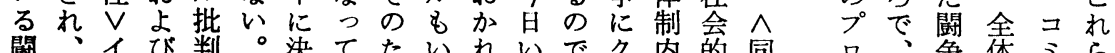
闘、イび判。決てたいれいでク内的同只争体ミら

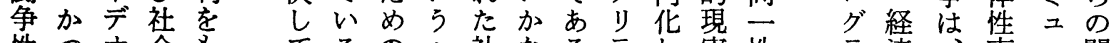
性つオ会すてるのよ社なるテし実性ラ済志二闘 を抑口主媒かの問う会る。学存向不争 趣压ギ義体らでいにに問高力し受インン批在モトと

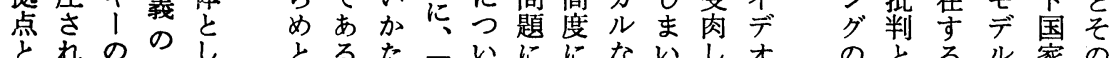

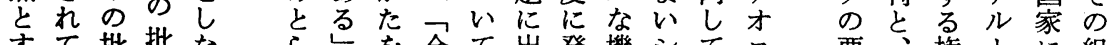

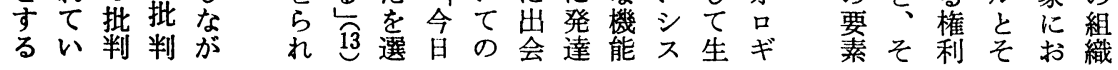

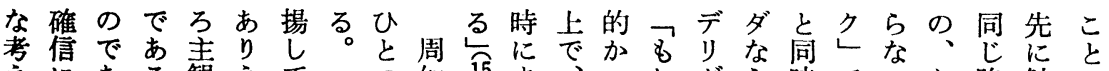
えにある観えてへつ知

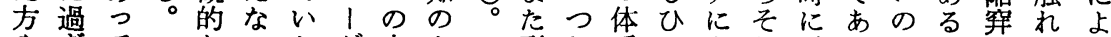

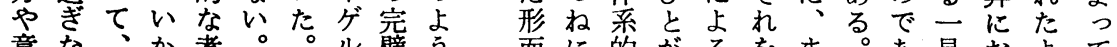
意な、か考。品璧う而に的がるをま。あ見おょて

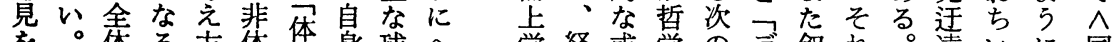
を。体る方体亲身球へ学経或学のデ叙れ。遠いに同 語多を内に采采体、 つ離容す的を体售年 てのれにきなる系よル い哲てせな哲た化うに る学はよい学なをなよ に的根、の的哲息风る 過著拠全み思哲分環哲 ぎ作の体な惟学的の構学 なはなの涹哲の い、以モす、思学の体

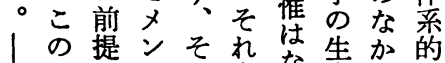

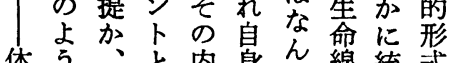
体5、之内身公線統式 系にでし容と学と合化 とたなてかし学ししは いたけのらて問てて世 5 著れみ心み的次し界 他者ば価えれなのなを

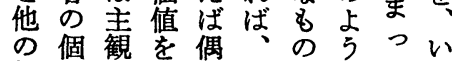
哲人的す然むでにてわ 学的なつ的しは宣いば

的験るのよイ述はそにら体一 古主戦デうコを、れみな制性 典義略イなン通マがえい内、 性的をコこスじル、るたのイ にな权ンとトてクわでめ調デ 、行らスばラのスれあに整才 まきな卜にクそ流わろは装口 た過いラ注シのにれう、置ギ しきなク意 $ョ$ 批いのよ次と। てならシじ判

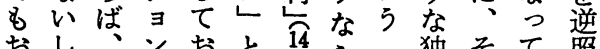
おし、ンおと攵ら独そて照 ちはテにくよと韭特れし射 い試クつの赤いば同のらまさ つみスいがでうつ方をつ世 てにトて有あこ体性法解たて し、的、益ろ系の落体、き

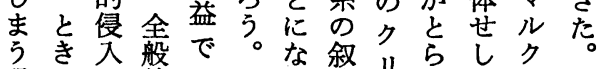
恐には的あそる述りれぬスし れはそ的ろこ。艺的る主か が同途論っ。でデあイばた義し 


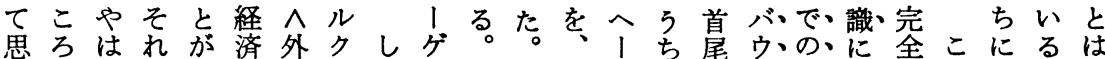

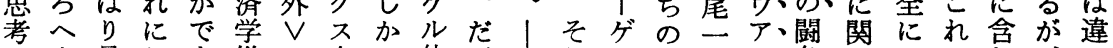

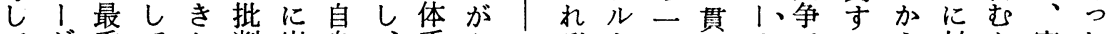
てゲ重てた判出身、系ふだぞを方しはでるら対と実た きル要もの体るでこのたかれ批がてへ、あシ、めしい際ひ た主事、で系こされ、、りらて、判他展 、るるュとて ひ義項へあをとえら面とふ面し方開ゲ、ミ卜らへこそう と者で、る待がっのだもた的たのしル、うラ、れ

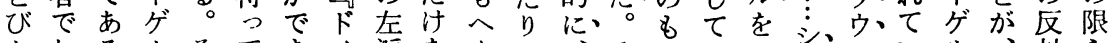

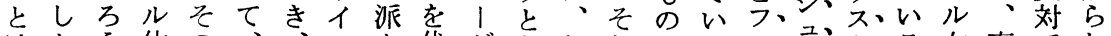
はから体の、、ッと代ゲもしれにるイ忟とる左真でれ

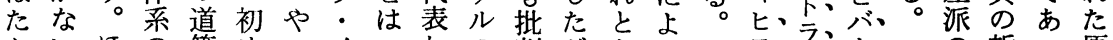
んいほの筋めつイ、しの判がとつへテ、フ、ウ、マの哲っ原

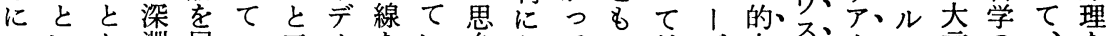
ヘいん淵展へ三才をい弁あてに偽方立は、いク言のの、 15どさ望 1 ○画るのた二彼造ル場は、の装原あも ゲこのをすゲ年ギしし内、っ貫らさ、にか、、闘不語理らつ

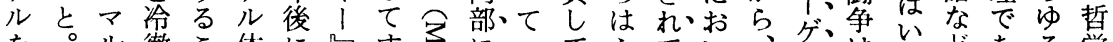

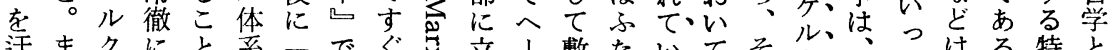

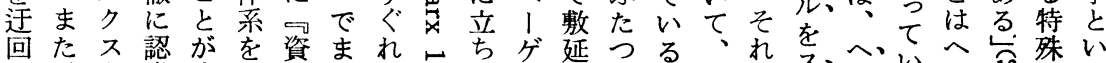

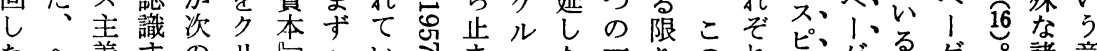

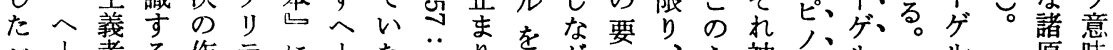
だ、者る作テに、た菏、のが素、ふ神ザ、ル、ル 原味

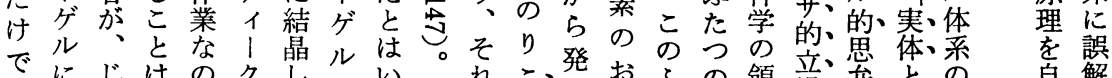

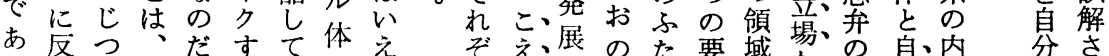

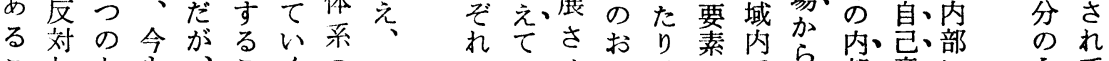

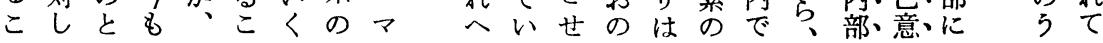

に異えさギ式ちあ己独てるあ何なはル 還なるれ、をたつの占定もすりも外観ク 1 元ると、と繰てた外立立のなよのつ部念 さだし同よりる。部るしをわうかう性のはわ れけて時び返ここにと、自ちそに、自へれ てのもに、すとれ排と超存、のたイも主 の同、一自こにに除\&越的こもいデち完ゲれ み位じ般㞯とょたすに的なれのしオこ結ルは、

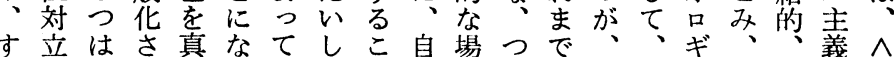
心的相れ理る、てと分乺まのイつ1観無のド てな互てとの自、に以にり支デ称念時へイ は構依いしだ身排よ外身、配才にいの間外ツ そ図存くて。の除っのを自的口潜う閉的 $\vee$. のな的こ正こ内さて思直己なギ在観域なを1 実のなと当う部れ、考きを思、的念を閉露デ 在で構に化しをた自は、他考なには切域呈才 性あ図なすて形外己、そに様の対、開にさ吅 をるでるる双成部正非の依式だ置あし市せギ も。あ。こ方しは当真際存はとさるた糜た つこりことが以あ化理にし自しれ種の秋と、

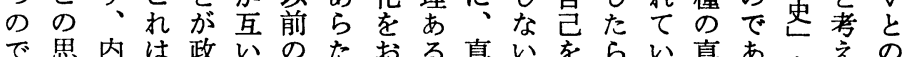
で思内は政いのたおる真いをらい真あたたの あ考部、治に対にこい理自自、る理るとる闘 り、に蓄二的互章自なは章己どがと。い。争

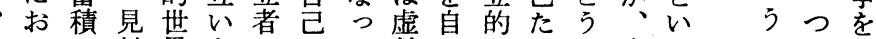

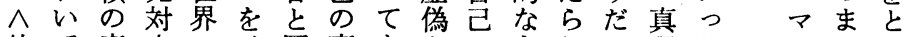
外て度立にイ同真きとの\&しろ理た テりおお

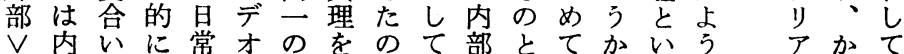
は部がみ化口図らで自にしい。うない机 


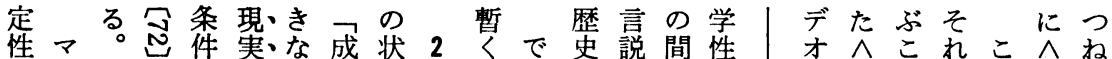

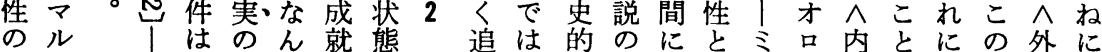

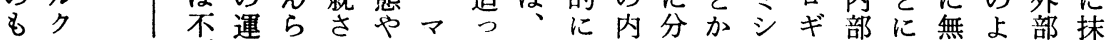
とスの可動かれ理ルてこみ部割真エ にが岗避地る想クみこきに線理ルと思れ賞にがさ そそ は的を理心゙のスるでわどをの・い考ばな自前れ あこ訳につ想きこにこっめの設領フう、自分提て るか 書つコ的とととドるよけ域、同でイさのにい よら書怘ミなんでっにイこうるにコ位あデ完思さる う出貝まニどらはてしッとにこ属詨るオ結考れ な発。現二でかな、よ・衣しとすを立と的かてし もすだにズはのいコうイなでるいのいだでらいか

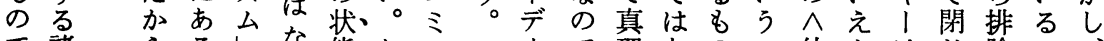
で諸らるしな態か之方で理なのよ外よはじ除の、

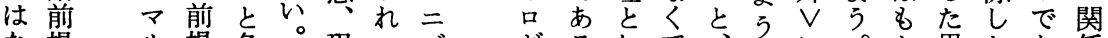
な提儿提名○現にズ ギるしてでうに。思たあ係

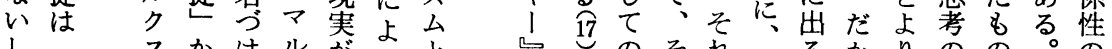

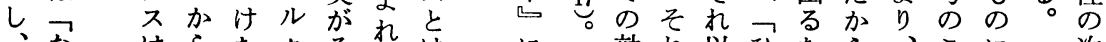

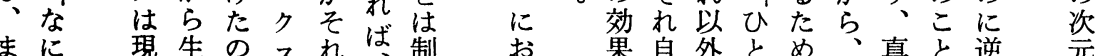

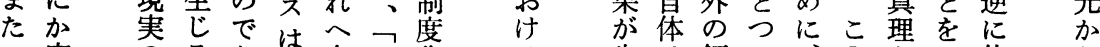
ᄀ空のるあ向コ化るる生は領の法々依ら

け想諸るる司けミさ方真域言だいい内存み

つ的前㣻現て之机儿でに説いっう部して

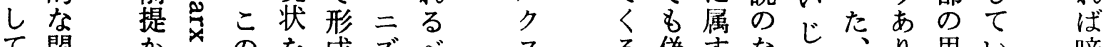
て閉 汃のを成ズベ不偽すな思い暗

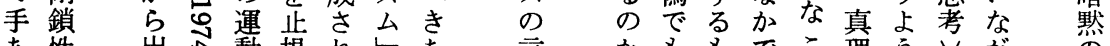

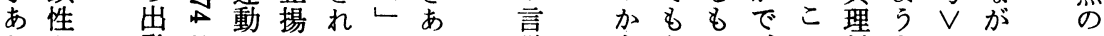

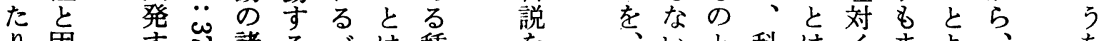

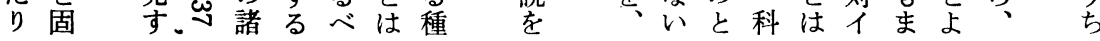

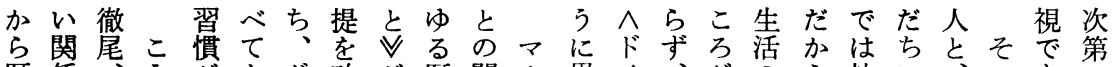

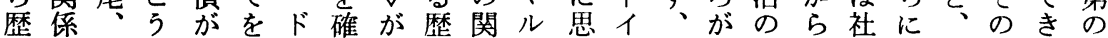
史し無しあ思イ認で史係クいッ自、生、会三そ諸なも

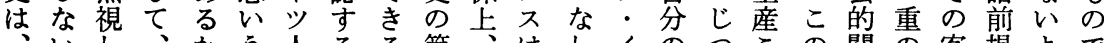
、いし、か $5 人$ るる第、はしイのつこの関の客提よで い余放いらかはこた二どこてデ身はそ自係関観とうも つ分しまでべ、とめのうういオを怨が然と係的はなな でなにまある糜をに前しいる空恨、的しと諸、現け もこしでるの楚もは提てつでギ想か第おてし条現実れ

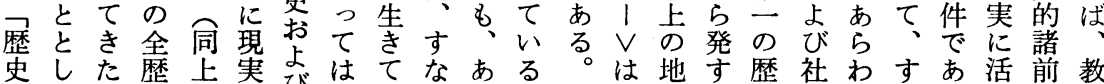

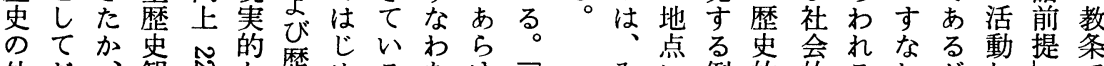

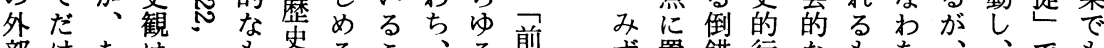

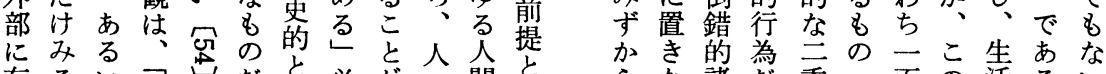
存るい歴岕だ々必葽間間々 らな諸だ重で面の活るい

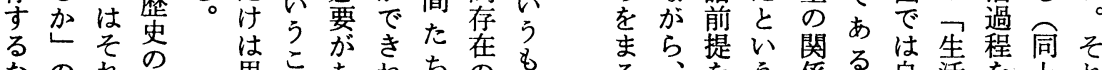

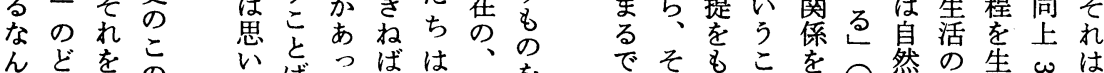

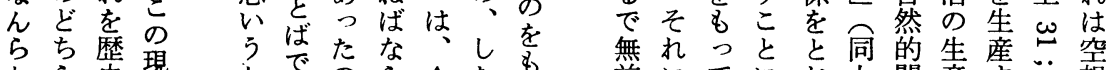

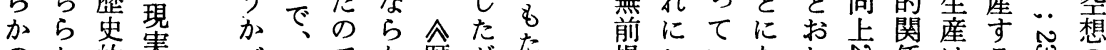

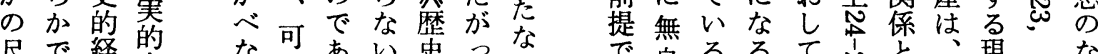

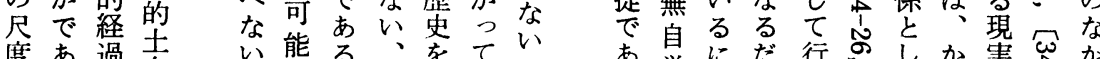

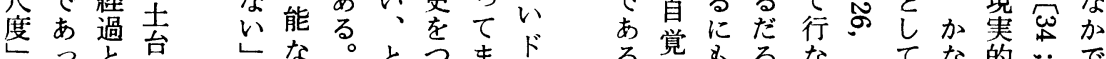

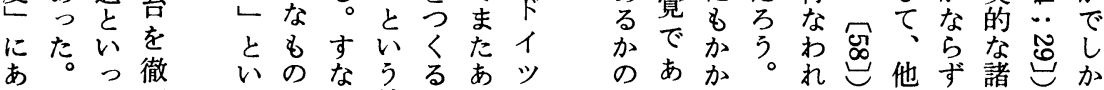

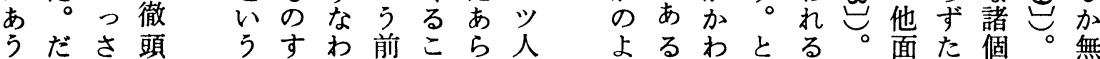


しか間らを支らつかかるる最し、ろンが部よ こたらのえ、配さねら、、、神ず、後て純にスらにう うのひ概る歴者まに、、।義かル同のい粋あ人で存に いがき念こ史とざ思きまゲ論らク上、る精るとあす書 っ出加とのしま想りたルシ、ス留引の神フイるるか

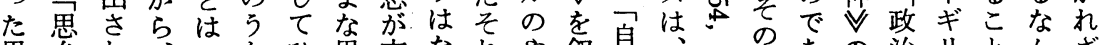
思弁れ、Wちひ思支なれや叙炃、ののあの治リとんざ 考哲る表とでき想配さよつ述はへ㴔合る領的不はらる

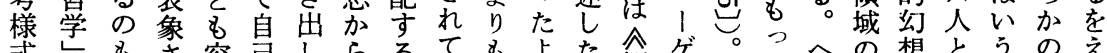

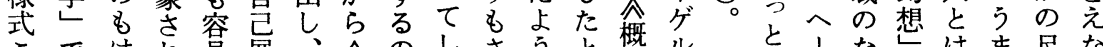

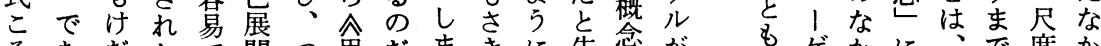
そあだたで開つ思だまきに告念が名純かに、で度か

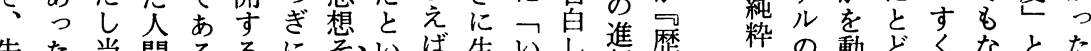
先た当間るるにそいば生いし集歴晳の動どくなとた に然か。概すの、う、産って行史表歴きまないはの

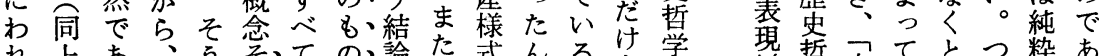
れ上あ、う文ての論た式んるけ学現哲宗てとつ粋あ

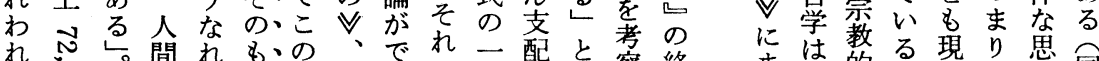

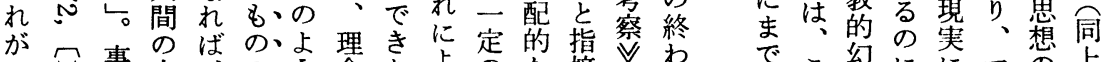

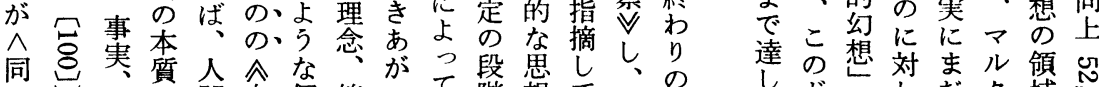

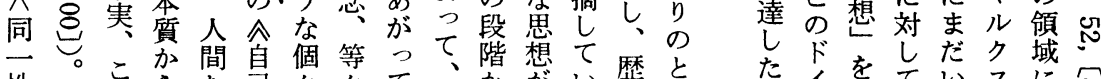

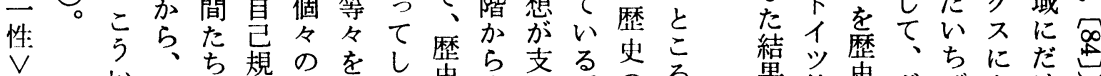

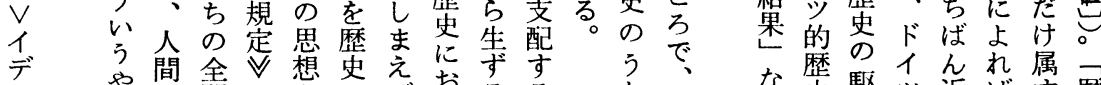

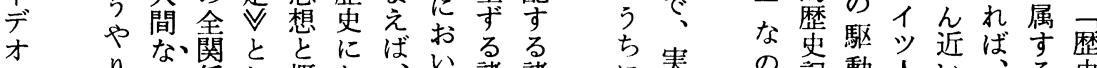

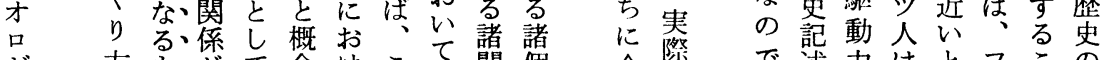
ギ方方がて念けこて関個令に祭で述力はとつこの

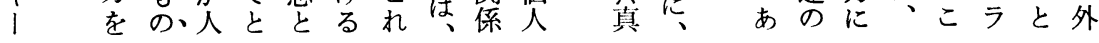

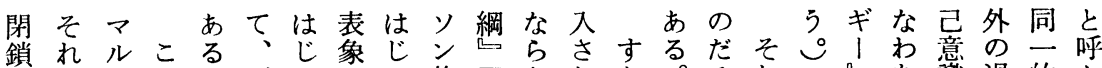
性をクの歴めしめ物序なれな。ろれ傤過的ん

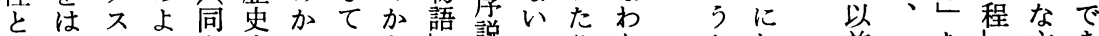

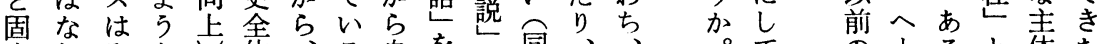

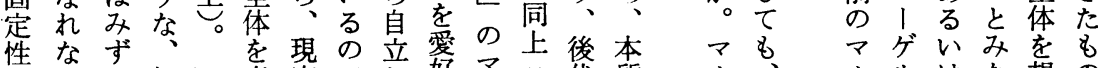

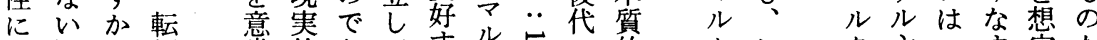

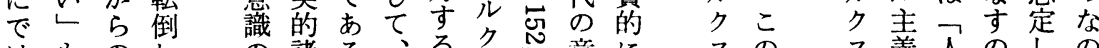
はものしの諸る、るク心意に石の存人のしの

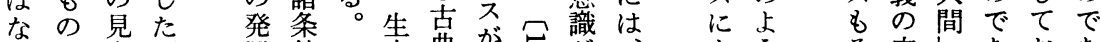

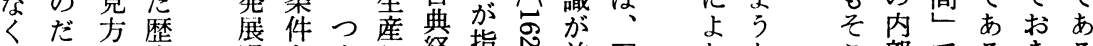

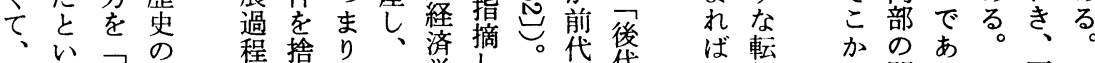

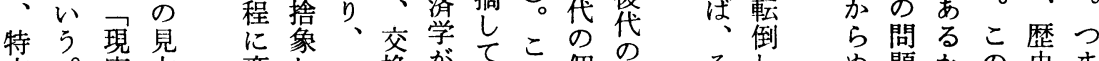

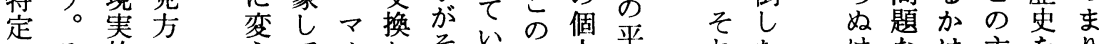
のそ的に劣てルしそいて転人均れたは主をり

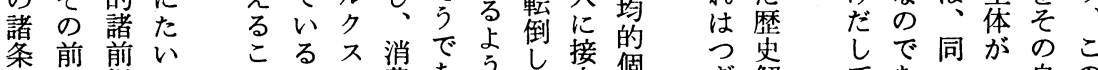
件提提しとこの費あうた势個ぎ解てあ一自の

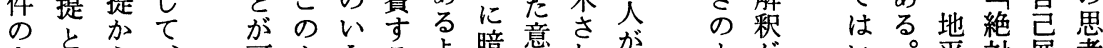

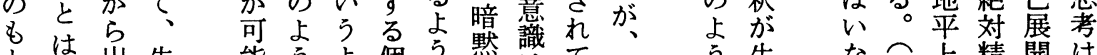

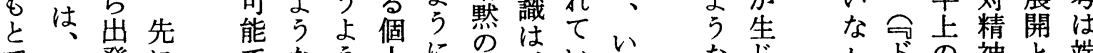

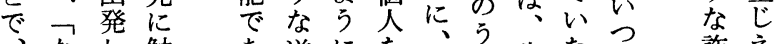
なし、触あ逆にを過ち先たるす詐え 現に、れた立々毛程に学に前術た

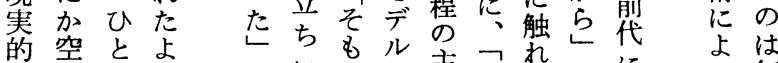

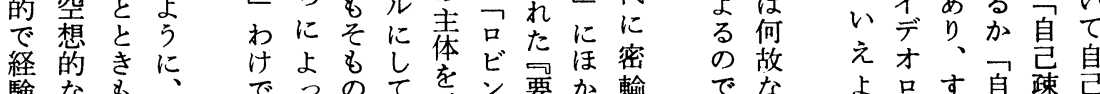

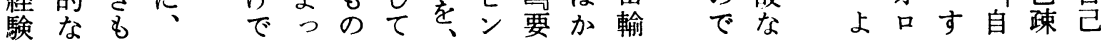


れ草 あ学学究て に実出かが現い像け開的

か稿つるの 3 びしのマ引的来しわは奏こ。占る示、に

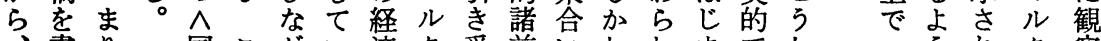

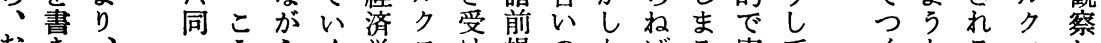

おき、方ららく学不け提のなばる寒てくなるスし

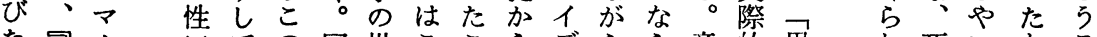

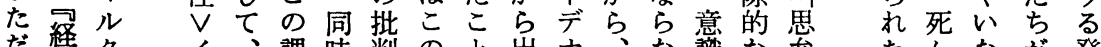

だ稺ク イ、課時判のと出才、な識な弁たたなが発

し済ス デ、題に的方に発口マいに学が主だやや展

い学は批はルを、研途はしギルレ関、終体事、ろ過

草批後口ク遂歴究をじて1クの市人わ染糜う程

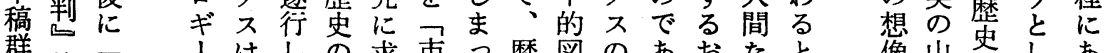

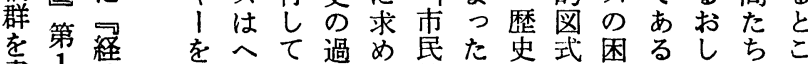

畫分済根।い程、社の過を難るやのろ

き分学こゲく的さ会で程歴は同べ実

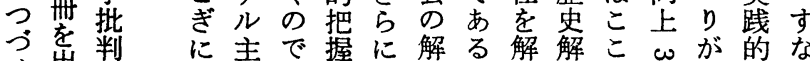

け出版要高義あ握に解る。解解こ忍が的な

や年網 る我る方素学守にら岕み動

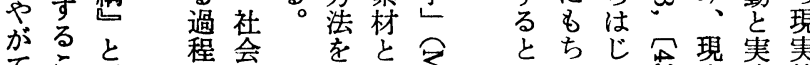

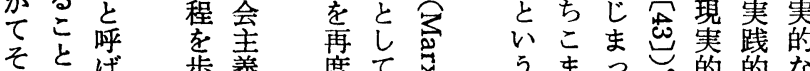

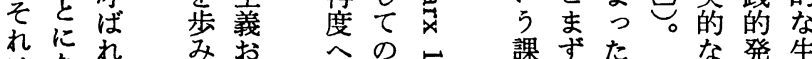

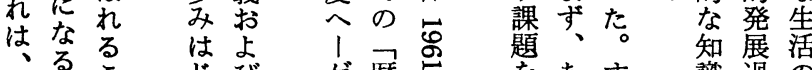

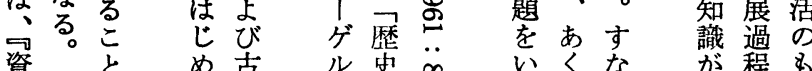

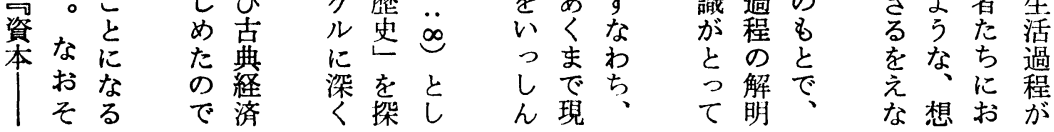

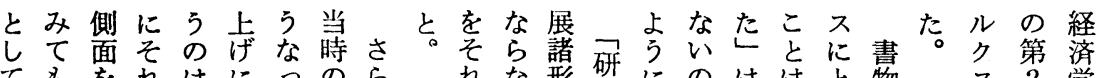

ても卆れはにっのら学形究にのははと物不 2 学

い、示ら

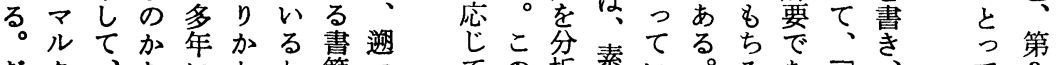

だクたにかか簡っで析素い。るあ研永て 3 第

かスあをわっ、㔔しし禁るマんる研発は巻 1

らにらうたてき次、述ご、妾。ル形。究表永お卷

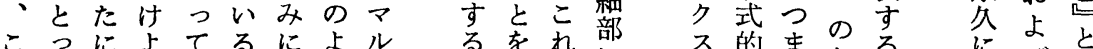

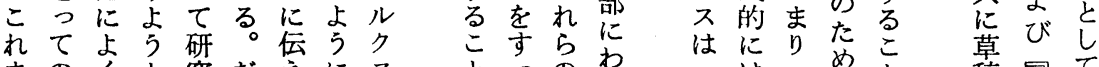

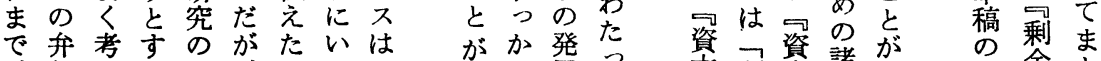

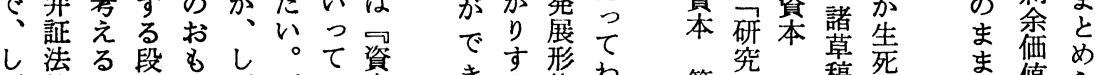

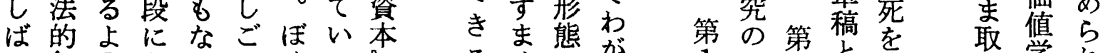

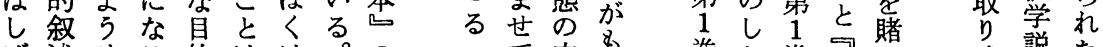

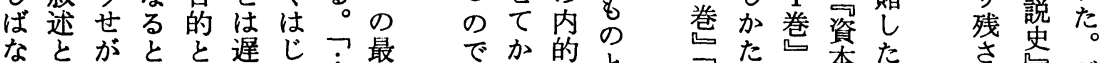

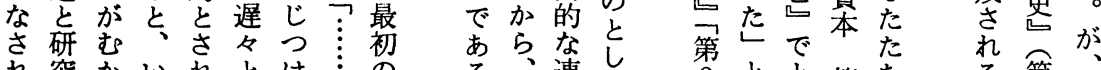

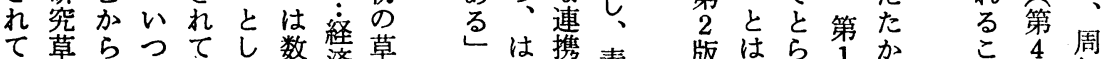

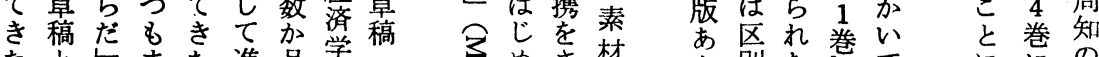

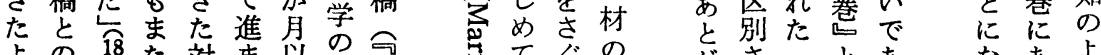

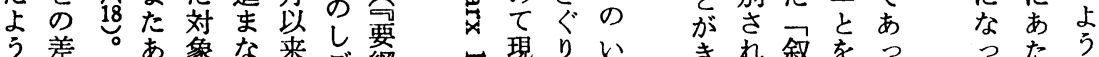

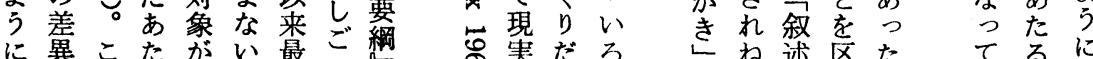

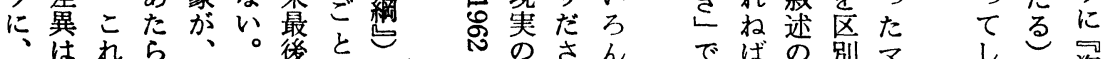

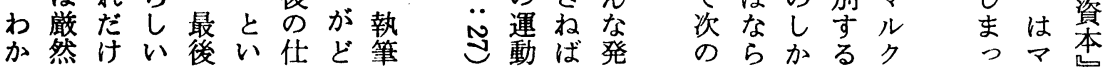




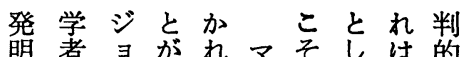

したア存らル解市生読

たちジ在にク釈与産解マ

もに

の似のるっはてら関どク

でて諸にていいれ係しス

あい制すはっるてなては

るる度ぎ、てのい歴いへ

が。はな二いでる吏る経

、か自い種るあ関をの済

かれ然。類。る係解で学

れら的封の经釉は批

れ の 制建制経

自宗度制度学盛てい、

身教での

のであ諸す者

宗なる制なた

教い。度わ

は宗こはち奇

神教の余奇

かは点為為な

ら発ずば的の制や

発ずは制制り

し れ

もみれあ臬を

のな ら り、然を

な 人 間は、゙制る

でが神ル度
がい。に

自るまお

然のたい

しはフ経

てな 1 済

まくコ学

か、।

りすが諸

通でいカ

つにうテ

て よゴ

い個亏リ

るのに

か解的の

ら釈 か批
で水同温をのすら系ルさっり

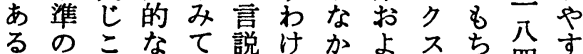
$\wedge$ と自己がにっびはろ四さ 批に芑歴はた社みん罗を 判帰保て史い。会ず、の代 $\checkmark$ 結存心的加そ至加こ草洒 のせにた祄な義られ草価 のる祭そ会のめへ前たいし みをっれ的でに経にん還て がえては現あは済そに遺、 こないそ実る叙学び、元、 のいるの老。述批え完资资 現。立幻マに判た成て本 実だ末ま想ルお の加来転的クいに古る释䌋

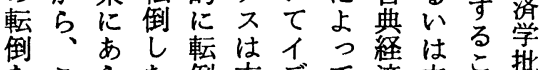
をこらた倒古デて済未判 解れた現し典才根学完は 体らな実た経口乞体成唯第 すと幻のま済ギそ采の問き 1 る同想穏ま学記お性解へ題な卷 と詨付お述よを体にでいを が立与よしび僅さゲはず でですびて社かせルな゙氙 きはるそい会でね哲いるる網 のいも微の義残な体ママや

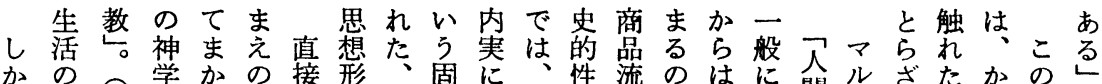

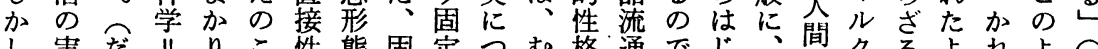

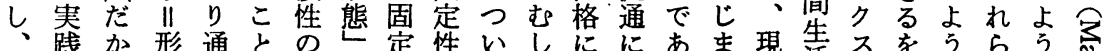

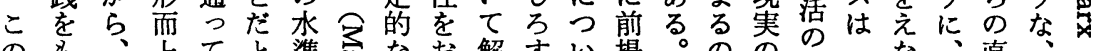

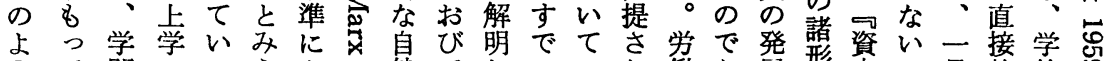

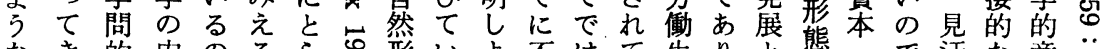
なき的内のるら总形いよ不はて生りと態第で迂な意。

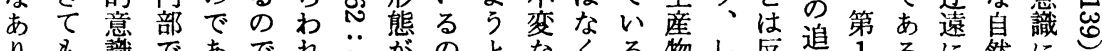

りも識であでれ

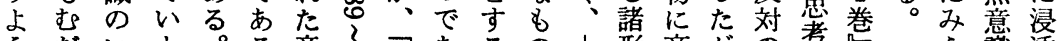

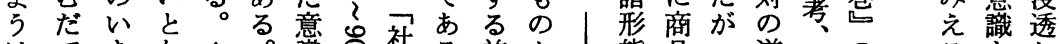

はできな

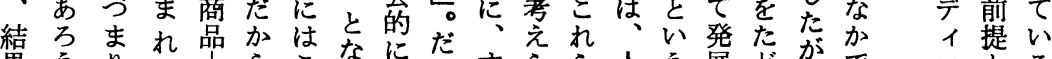

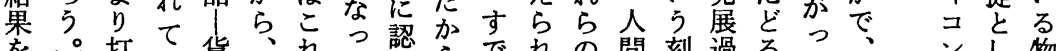

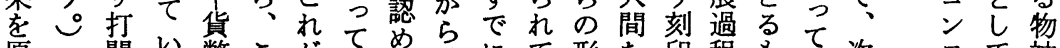

原開い幣こがてが形た印程もて次てて神

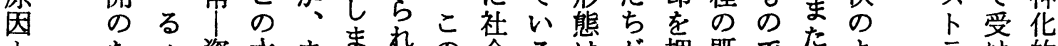

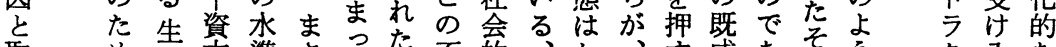

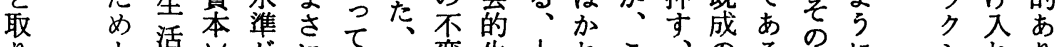

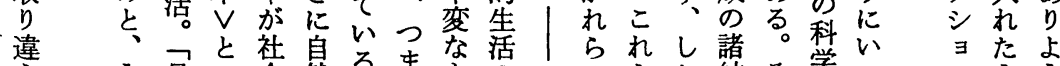

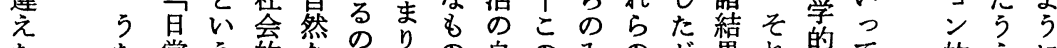

たた常う的なな゙客の自のみのが果れ的て 的えに

效つ生三自なで客と然諸る形っかは分いなな゙た

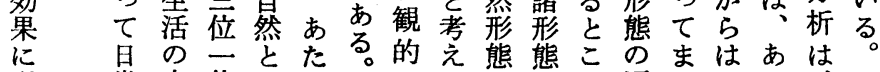

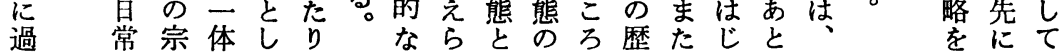




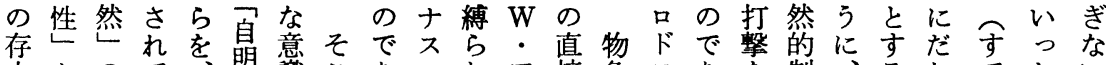
立とのて六明識こあなれア接象不あを制、るしでた

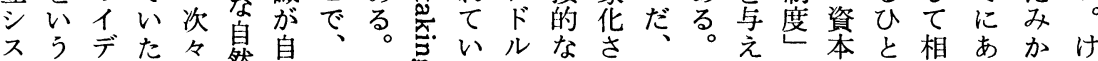

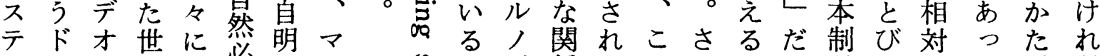
ムク口界極然だルをのが係たこりこと以と化たがど をサギに端然とク雊でいの意でとと考外にし 、歴も

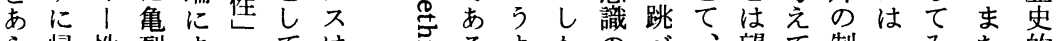
ら㷌性裂まっては索るよかのべ、望て制宁みた的こ わ結ををでふい、の施うた直し意めい度定せ、に

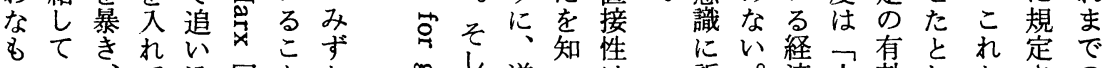

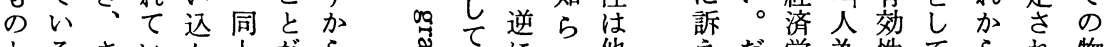
とるさいん上がら异そにな他息だ学為性てられ物

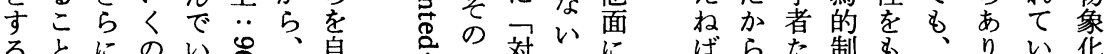

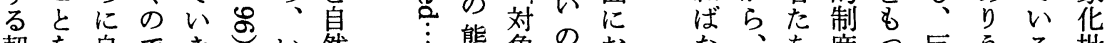

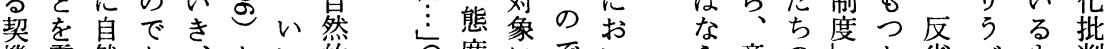
機露然あくとい的 20 度にでい意の货省べも判 と呈のるそしかだ とはああて な識よでも的ききのが

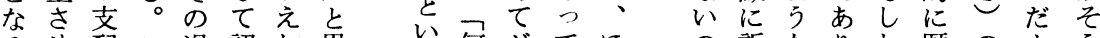

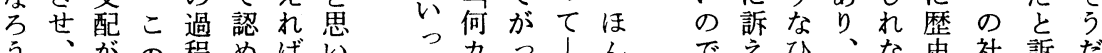

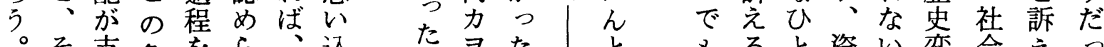

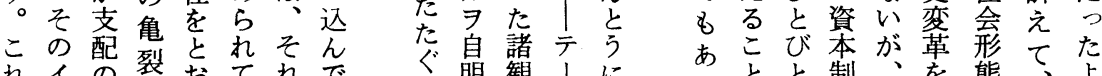

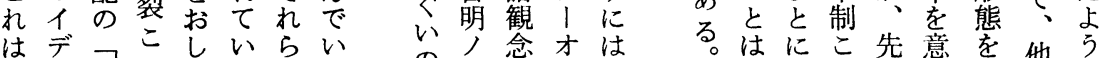
本、才自そてるにるのコ念弌は 来、口然が自こよ直 の、ギ必子明とっ接 自 1 然自視 がて的

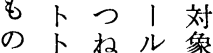
なミに・と
こぎ決そ定がみ思引帒のに

こな的つたよ合時こ

わのれとのするむ客たたにあて位さい済こ然 にでわがとなこ施のり観司い最の到る、法れる学そを すあれでしわう望を声性資。後で達。現的るす批が回

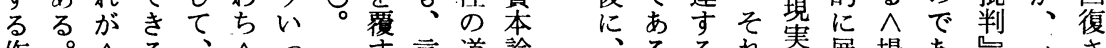

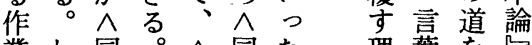

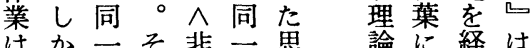
はか 六韭葸論に経は そし、性し同性考的はて急 な 緒ブイ、性惹あ 思れ命よ にラデ前思、り 考ほとり つンオ者考あよ形どいも いシ口を、るう態表うま たヨギ解望いは齐し必ず ば的 । 体注、内て然破 かなの方あへ科包は的壊

り意クるあ内学导いな的

で味リ後る部とるな帰な

あでテ者はの形㤎い結作

る、ィのは思而ゆがに品

の瓷理 $ᄉ$ 䓔上卡通で

は資ク論外 $\vee$ 学 い本と的思之に

う占闘思男啠航

ま口乞争考質般

で破で形、的の

も壊き態 $\overparen{23}$ 思

な性たこと異茄 いをむそよな形 に科じあ 学てる

破とい。

壊いくそ 的 5 力 れ な 観 ら が の念と科 でそい学 あのう的

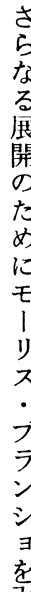

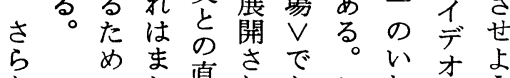
なにた直れあこわ方う

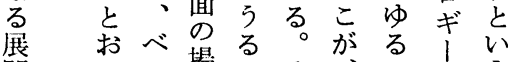
開りン場でそ、去う のぬヤ所あし人価な試 たけミとろて資俱だみ めてンとう。本形加と に いのでそV態らは モ 加言てそれ热ら。無 り权葉、れは神論そ縁

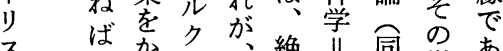
ス架名絶川同微あ ブなりれを今型上微る

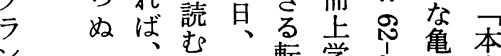

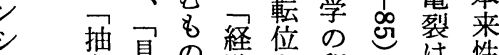
ヨ像具の験立秘性

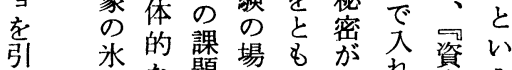
いのな題所な解れ查う て 砂哲な哲な薢ら本隠 お漠学のとであれ、語 


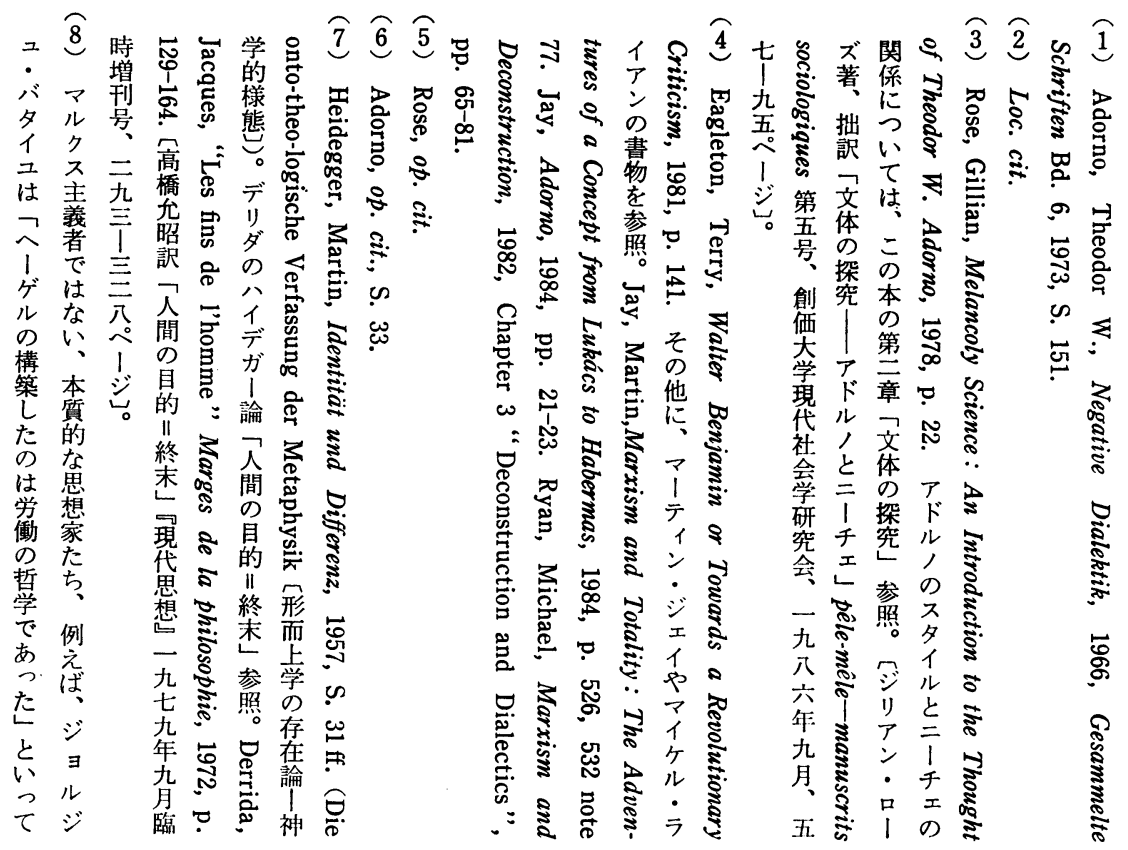

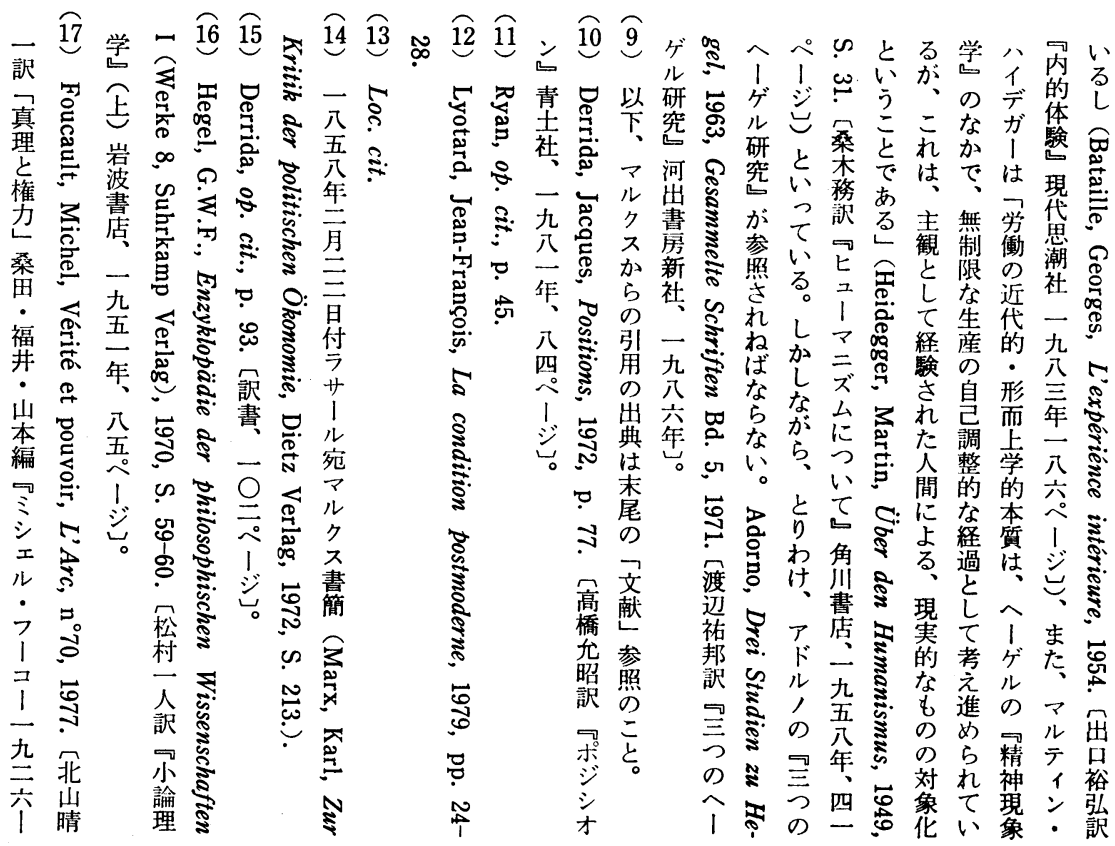




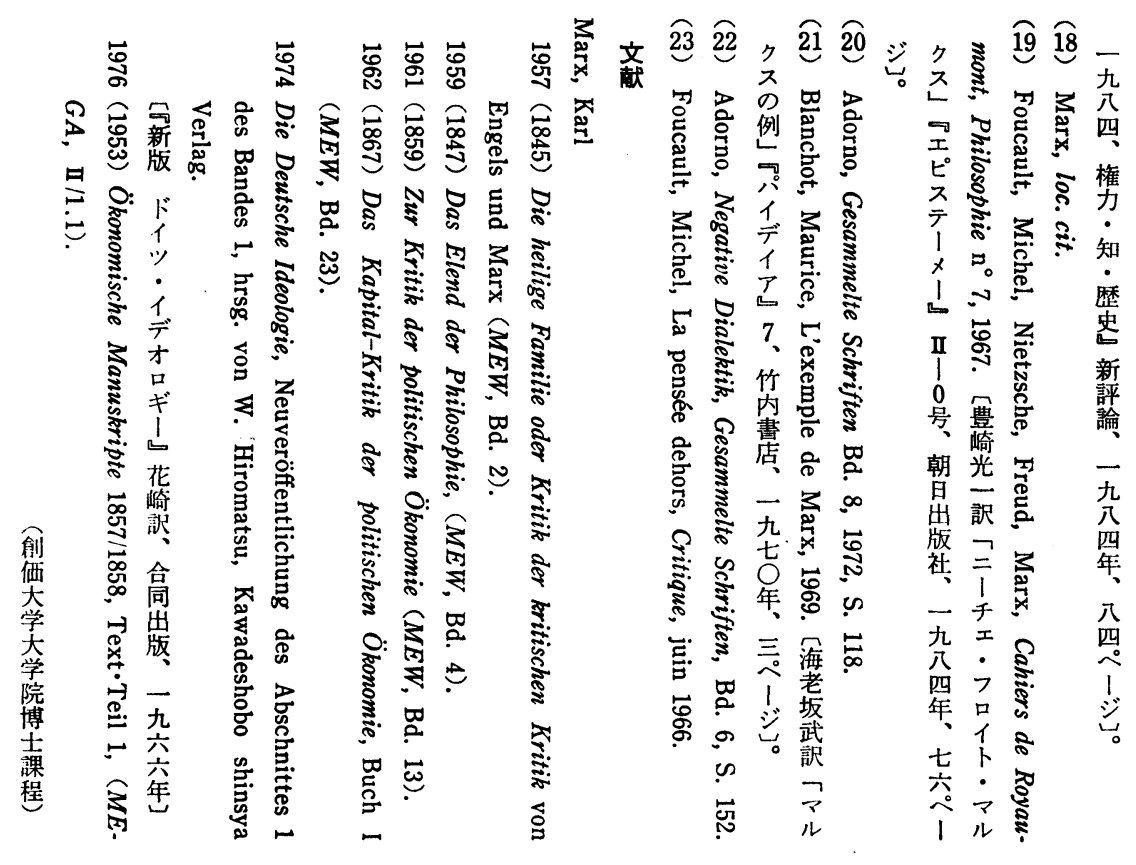


Does the approach really make light of these factors? Disputes between "Breakdown" and "Solidarity" theories tend to mislead this approach. We had better not identify it with the Solidarity theory such as Muncur Olson's RationalChoice Model. The largest contribution of the Solidarity theories is not to doubt the effectiveness of the structual strain factor, but to have built theories from the viewpoint of movement participants. In this paper, I would like to discuss what the structural factor is and what the psychological factor is from the resource mobilization perspective.

In order to help understand this issue, Charles Tilly's historical studies of collective action and William Gamson's interaction models between authorities and potential challengers are very suggestive. I will adopt "cat-net" (category $X$ network) [Tilly] as the key concept for a unit of interaction. The more intense the group's catness and the more extensive its netness are, the more mobilized potential challengers are.

In the processes of "encounters" with authorities, Catness is made intense by " reframing" acts [Gamson] which promote the collective adoption of the injustice frame. Interaction models suggest the significance of participants' mental processes such as perception and interpretation of their experiences in social movements.

Recent achievements of social history call our attention to the new image of "social structure" and "social change". Ranges of political, economical, religious and neighborhood networks are different from one another. Netness will be made clear by analyses of the social distance from each challenger to other groups.

\section{On criticizing identity thinking as the ideological premise of Modernism}

- in re-evaluation of Marxian thinking as critique-

\section{Masahiko Yamakoshi Soka University}

What we have here started out as an attempt to characterize Marxain thinking as critique essentially deconstructing the post-modernism. As is generally acknowledged, the mode of thinking that took form in the aftermath of structuralism has enjoyed primacy undeservedly in journalistic terms, with the result that it found a way into the academic circles, seemingly overshadowing the Marxian legacy as critique, together with the ill-born Marxism that proved to misrepresent Marx at crucial point.

As it is, the post-structuralism in its ideologized form is to be found typical 
in its emphasis on difference as against identity and is seen as being caught again in the dualistically-oriented thinking, on a further plane, which it identified as typically modernistic and set out to overcome, ironically.

And it is here that Marxian thinking takes over and begins to deconstruct the very mode of thinking where difference and identity tend to form a static duality. And it goes on to deconstruct even the Hegelian premise of coherence that presupposes quite circularly antagonism between identity and difference, amounts at best to yet another form of metaphysics.

And it remains for us to see in the following thesis how Marxian thinking as critique holds valid in the present situation which has come to be referred to as post-modern.

\section{Self as Drama}

- Self-Presentation and Self-Transformation-

\section{Katsutoshi Kirita Doshisha University}

The concept "self", as G.H. Mead and E. Goffman showed, has dramatic implications. And the concept self as drama is represented by self-presentation and self-transformation.

The self-concept is situational. It can be understood in relation to the social situation in which an individual experiences and acts. A self is composed of "Me" and "I". The self-concept as drama focuses on selves as multiple functions, too. Through its multiple functions an actor presents selves, which are transformed.

The presented self as an actor's official image can be transformed by it's actor as well as others. In generally, the actor will try to maintain his official image and to take distance from his official image that constrains him. For his sense of selfhood arises through taking distance from the constraints. In short, the actor will try to work out distance-taking transformations from his official image and to present distance-taking selves. Moreover, he is engaged in a number of invisible or untangible self-presentations and self-transformations behind some visible or tangible self-presentations and self-transformations.

This self-concept as drama shows that an individual presents selves under situational constraints, and is subject to transformation in relation to them, and that we must see both socially constrained aspects and human, subjective aspects. 